\begin{tabular}{|c|l|}
\hline Title & $\begin{array}{l}\text { Oxygenated sterol derivatives. their identification from the fungus-infected silkworm carcass, } \\
\text { bombyx cum botryte and their effects on growth and sterol metabolism of the silkworm, bombyx } \\
\text { mori }\end{array}$ \\
\hline Sub Title & \\
\hline Author & $\begin{array}{l}\text { 応, 百平(Ying, Bai-ping) } \\
\text { 森崎, 益雄( Morisaki, Masuo) } \\
\text { 池川, 信夫( Ikekawa, Nobuo) }\end{array}$ \\
\hline Publisher & 共立薬科大学 \\
\hline Publication year & 1984 \\
\hline Jtitle & $\begin{array}{l}\text { 共立薬科大学研究年報 (The annual report of the Kyoritsu College of } \\
\text { Pharmacy). No.29 (1984. ),p.41-42 }\end{array}$ \\
\hline JaLC DOI & \\
\hline Abstract & \\
\hline Notes & 抄録 \\
\hline Genre & Technical Report \\
\hline URL & $\begin{array}{l}\text { https://koara.lib.keio.ac.jp/xoonips/modules/xoonips/detail.php?koara_id=AN00062898-0000002 } \\
9-0041\end{array}$ \\
\hline
\end{tabular}

慶應義塾大学学術情報リポジトリ(KOARA)に掲載されているコンテンツの著作権は、それぞれの著作者、学会または出版社/発行者に帰属し、その権利は著作権法によって 保護されています。引用にあたっては、著作権法を遵守してご利用ください。

The copyrights of content available on the KeiO Associated Repository of Academic resources (KOARA) belong to the respective authors, academic societies, or publishers/issuers, and these rights are protected by the Japanese Copyright Act. When quoting the content, please follow the Japanese copyright act. 
No. 29 (1984)

\section{Oxygenated Sterol Derivatives. Their Identification from the Fungus-Infected Silkworm Carcass, Bambyx cum Botryte and their Effects on Growth and Sterol Metabolism of the Silkworm, Bombyx mori*}

Bai-ping YING, Masuo Morisaki and Nobuo Ikekawa

応 百平**, 森崎益雄, 池川信夫***

Oxygenated sterol derivatives such as 7-oxocholesterol (2), $7 \alpha$ - and $7 \beta$-hydroxycholesterol ( 3 and 4 ) and 25-hydroxycholesterol have been shown to be potent inhibitors of sterol biosynthesis and $\beta$-hydroxy- $\beta$-methylglutaryl ( $\mathrm{HMG}$ ) coenzyme $\mathrm{A}(\mathrm{CoA})$ reductase activity when added to mammalian cultured cells. Following the blockage of sterol synthesis, the concentration of sterol in the cells declines, growth ceases, and eventually the cells die. On the other hand, Cheng et al. isolated ergosterol peroxide (1), $7 \alpha$ hydroxycholesterol (3) and 7 $\beta$-hydroxy-cholesterol, -campesterol, and -sitosterol (4-6) from Bombyx cum Botryte, consisting of silkworms (Bombyx mori) killed by infection with the microscopic fungus Botrytis bassiana Bals. The "animal drug" B. cum Botryte (㢾覔) has been used in China for treatment of several diseases including cancer, and some of the above-mentioned 7-hydroxylated compounds and other oxygenated sterols were reported to be cytotoxic to rat hepatoma cells.

We considered that the death of silkworms following fungus infection might be due to the cytotoxic effect of the oxygenated sterols, which may be produced by a cooperative action of the host (silkworm) and invader (fungus). However, since the insect lacks de novo sterol synthesis, these compounds should be nontoxic to the insect if HMG CoA reductase is the sole target enzyme involved in the inhibitory effect of oxygenated sterols. In order to examine these possibilities, we first attempted to confirm the presence of oxygenated sterols in B. cum Botryte, and then the effects of several oxygenated cholesterol derivatives on the growth and sterol metabolism of the silkworm $B$. mori were investigated.

The sterols 1-6 were identified, albeit in very minute amounts (less than $1 \%$ of total sterol) from $B$. cum Botryte by gas chromatography-mass spectrometric analysis.

Then the larvae of the silkworm $B$. mori were reared on a diet which contained $0.1 \%$ cholesterol or sitosterol in combination with $0.01 \%$ oxygenated sterols $(1,2,4,15-$ oxo-5 $\alpha$-cholest-8(14)-en-3 $\beta$-ol, (20S)-20-hydroxycholesterol and 25-hydroxycholesterol).

* 本報告は Chem. Pharm. Bull., 32, 3003 （1984） に発表

** 中国科学院, 上海薬物研究所

*** 東京工業大学理学部 
No. 29 (1984)

Most of the larvae developed to the third instar and survived at least till 20 days after hatching. Their mean body weights were not very different from the control value. It may be concluded that the effect of the oxygenated sterols, which were added to diet at a much higher concentration than was found in the carcass of B. cum Botryte, was too small to induce mortality of $B$. mori. Thus, the death of $B$. cum Botryte is probably not caused by the oxygenated sterols. 